\title{
MRI hydrographic 3D sequences in CADASIL
}

\section{Figure Subcortical lacunar lesions in CADASIL}
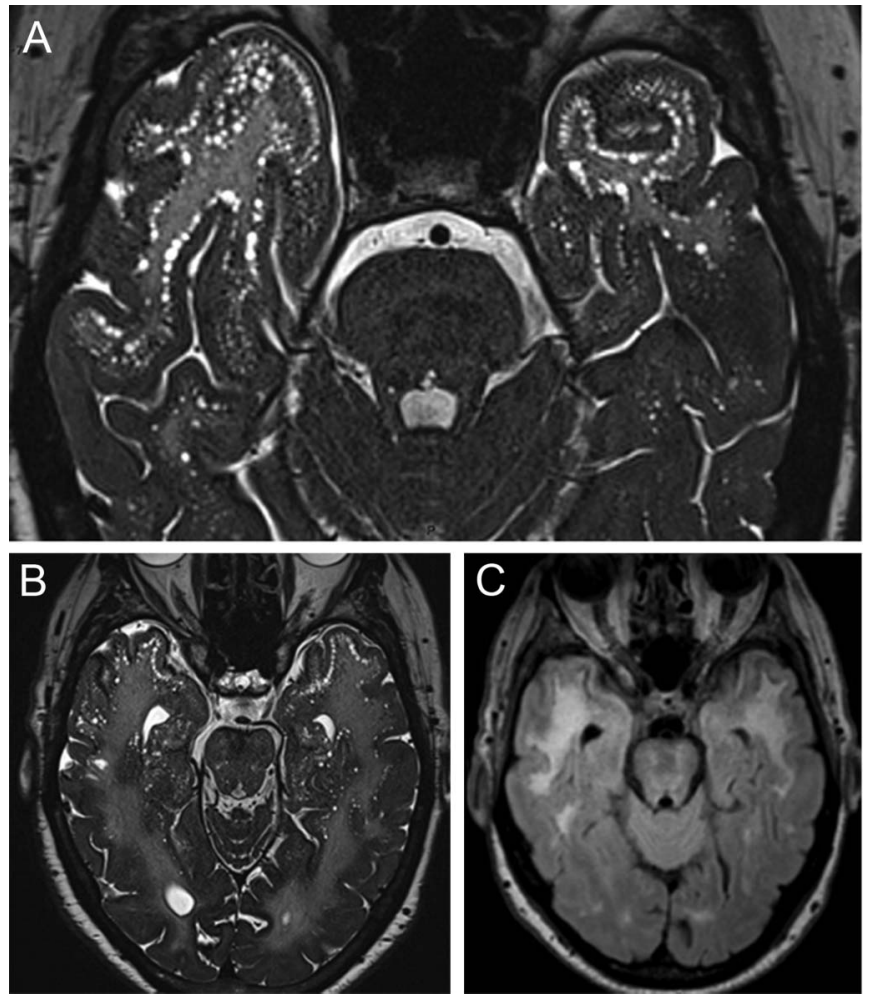

Brain MRI of patients with cerebral autosomal dominant arteriopathy with subcortical infarcts and leukoencephalopathy (CADASIL) shows hyperintense lesions on fluid-attenuated inversion recovery (C) associated with numerous subcortical lacunar lesions in the temporal lobes, best characterized by a 3D SPACE sequence $(A, B)$.

Two patients with cerebral autosomal dominant arteriopathy with subcortical infarcts and leukoencephalopathy (CADASIL) (figure), evolving with cognitive deterioration, had MRI. Hydrographic 3D highresolution turbo spin-echo (TSE) with variable flip angle sequence (SPACE) was performed to demonstrate the subcortical lacunar lesions (SLLs) (figure, A and B) considered specific in CADASIL. ${ }^{1}$

SPACE is a $3 D$ TSE sequence similar to other hydrographic sequences, in which the water and fat have high signal, giving excellent contrast between CSF and other structures; SLLs appear as linearly arranged groups of rounded, circumscribed lesions at the junction of gray and white matter with signal intensity similar to CSF, ${ }^{1}$ located mainly in the anterior temporal lobes.

Vanessa C. Mendes Coelho, MD, Débora Bertholdo, MD, Sergio Eiji Ono, MD, Arnolfo de Carvalho Neto, MD, PhD

From the Clínica DAPI-Diagnóstico Avançado por Imagem (V.C.M.C., D.B., S.E.O., A.d.C.N.); and UFPR-Universidade Federal do Paraná (A.d.C.N.), Curitiba, PR, Brazil.

Author contributions: Vanessa C. Mendes Coelho: main author and clinical history revision. Débora Bertholdo: contributor and reviewer. Sergio Eiji Ono: contributor and reviewer. Arnolfo de Carvalho Neto: intellectual contribution.

Study funding: No targeted funding reported.

Disclosure: The authors report no disclosures relevant to the manuscript. Go to Neurology.org for full disclosures.

Correspondence to Dr. Mendes Coelho: vanessa-med12@hotmail.com

1. van Der Boom R, Lesnik Oberstein SA, van Duinen SG, et al. Subcortical lacunar lesions: an MRI finding in patients with cerebral autosomal dominant arteriopathy with subcortical infarcts and leukoencephalopathy. Radiology 2002;224:791-796. 


\section{Neurology}

\section{MRI hydrographic 3D sequences in CADASIL}

Vanessa C. Mendes Coelho, Débora Bertholdo, Sergio Eiji Ono, et al.

Neurology 2014;82;371

DOI 10.1212/WNL.0000000000000056

This information is current as of January 27, 2014

\section{Updated Information \&} Services

References

Subspecialty Collections

Permissions \& Licensing

Reprints including high resolution figures, can be found at: http://n.neurology.org/content/82/4/371.full

This article cites 1 articles, 0 of which you can access for free at: http://n.neurology.org/content/82/4/371.full\#ref-list-1

This article, along with others on similar topics, appears in the following collection(s):

\section{CADASIL}

http://n.neurology.org/cgi/collection/cadasil MRI

http://n.neurology.org/cgi/collection/mri

Information about reproducing this article in parts (figures,tables) or in its entirety can be found online at:

http://www.neurology.org/about/about_the_journal\#permissions

Information about ordering reprints can be found online:

http://n.neurology.org/subscribers/advertise

Neurology ${ }^{\circledR}$ is the official journal of the American Academy of Neurology. Published continuously since 1951, it is now a weekly with 48 issues per year. Copyright @ 2014 American Academy of Neurology. All rights reserved. Print ISSN: 0028-3878. Online ISSN: 1526-632X.

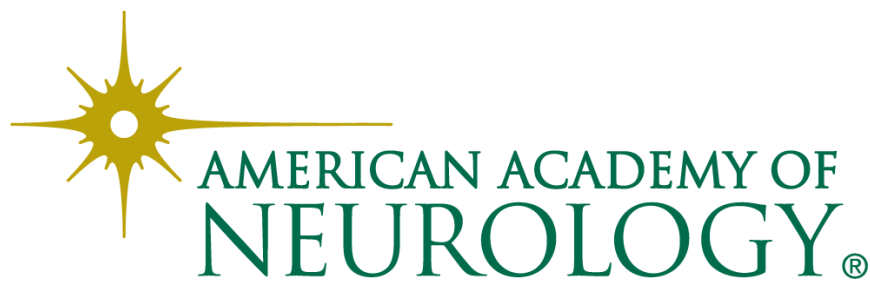

